Original Research

\title{
Analysis of Factors Related to Nursing Student Self Wareness in Doing Screening for Psychosocial Problems
}

\section{Verantika Setya Putri, Ah Yusuf, and Rr Dian Tristiana}

Faculty of Nursing, Universitas Airlangga, Surabaya, Indonesia

\begin{abstract}
Introduction: Mental health knowledge is a substantial part of mental health literacy. Many psychosocial problems are transient and are often not noticed. This study aimed to analyze the factors related to student self-awareness in conducting psychosocial screening.

Methods: This study used a descriptive-analytic design with cross-sectional approach. The study was conducted at the Faculty of Nursing, Universitas Airlangga Surabaya. A total of 160 respondents was chosen using simple random sampling techniques. The instrument used was a questionnaire. The dependent variable in this study was students' awareness in conducting psychosocial problems screening. The independent variables in this study were knowledge, social interaction, family support, perceived vulnerability, perceived severity, perceived benefits, perceived barriers, and self-confidence. Analysis used multiple linear regression statistical tests.
\end{abstract}

Results: The results showed there was a relationship between social interaction $(p=0.00)$, perceived vulnerability $(p=0.00)$, perceived benefits $(p=0.001)$ and selfconfidence $(p=0,000)$ with students' self-awareness in conducting psychosocial screening. There was no relationship between knowledge ( $p=0.555)$, family support $(\mathrm{p}=0.720)$, perceived severity $(\mathrm{p}=0.070)$, perceived barriers $(\mathrm{p}=0.748)$ with students' self-awareness in conducting psychosocial screening.

Conclusion: Mental health awareness in nursing student should be enhanced and strengthened with health education. Self-awareness of mental health is important for students. This can prevent mental disorders in the future

\section{ARTICLE HISTORY}

Received: July 1, 2020

Accepted: September 2, 2020

\section{KEYWORDS}

nursing students; psychosocial problems; screening; self-awareness

\section{CONTACT}

Ah Yusuf $\triangle$ ah-yusuf@fkp.unair.ac.id $\equiv$ Faculty of Nursing, Universitas Airlangga, Surabaya, Indonesia

Cite this as: Putri, V, S., Yusuf, A., \& Tristiana, R, D. (2020). Analysis of Factors Related to Nursing Student Self Wareness in Doing Screening for Psychosocial Problems. Jurnal Ners, 15(2). 178-184. doi:http://dx.doi.org/10.20473/in.v15i2.20395

\section{INTRODUCTION}

Anxiety is experienced by $75 \%$ of nursing students at Airlangga University. Anxiety is a symptom of psychosocial problems. Based on preliminary study on December 13, 2019, problems above $56.4 \%$ were caused by poor coping and $49.1 \%$ were due to poor time management. Other causes were too many assignments by $34.5 \%$, rescheduling schedules, and heavy credit load with a small percentage that causes students to experience physical and psychological fatigue. The results of the preliminary study said that nursing students did not consider the anxiety problem caused by physical and psychological stress required to be addressed immediately, they considered the problem to be a normal thing to happen. According to Ormel et al. (2020) this phenomenon illustrates that nursing students' awareness of psychosocial health is still low. The impacts felt by students due to the problems above include dizziness, diarrhea, increased stomach acid, and thrush (Ashley \& Reiter-Palmon, 2012). Other impacts such as college assignments that were completed but not maximal in doing so were $92.3 \%$ and unfinished college assignments by $13.5 \%$.

The prevalence of severe mental disorders in Indonesia is $1.7 \%$ and mental-emotional disorders reached around $6.1 \%$ in 2013 and increased to $9.8 \%$ in 2018 (Riskedas, 2018). More than 19 million people aged over 15 years are affected by mentalemotional disorders. The World Health Organization ( WHO, 2010) mentions the suicide rate in Indonesia reaches $1.6-1.8 \%$ per 100,000 people. The impact of extensive psychosocial problems covers all aspects of 
human life, one of which is productivity; this is a concern that needs to be addressed through preventive efforts. Secondary or preventive prevention is aimed at community members who experience psychosocial problems (risk of mental disorders). The purpose of this service is to reduce the incidence of mental disorders. Service targets are student members who are at risk or show signs of psychosocial problems and mental disorders. Screening is used as early detection of health problems. This is done through government programs that address mental health problems with health and screening counselors (Prince \& Alexander, 2017). However, these efforts have not shown maximum results, due to low mental health concerns, including a screening process that is not in line with community conditions, lack of human resources, and available health facilities (Andriyani \& Widigdo, 2017).

Self-awareness is influenced by demographic factors, including gender, education, age, and history of previous illnesses (Manurung, 2018). Psychological characteristic factors influence the courage to do screening as well as undertake treatment, while socio-cultural factors consisting of social interactions and family support affect awareness in screening; the more often a person interacts with other people the more experience and good socializing habits. This socio-cultural influence influences one's perception and belief in the problem of mental disorders. These factors are identified by the Health Belief Model (HBM) theory, which is a model used to describe an individual's trust in healthy living behaviors so that individuals will engage in such behaviors. Healthy behaviors can be preventive behavior or the use of health facilities. This health belief model is often used to predict preventive health behaviors. Based on the description above, the researcher will further analyze the factors related to students' self-awareness in screening for psychosocial problems at the Faculty of Nursing, UNAIR Surabaya.

\section{MATERIALS AND METHODS}

This research is a descriptive analysis type of research with a cross-sectional approach. The population of Airlangga Nursing Faculty students is a regular program and has passed the mental nursing course. This research was conducted at the Faculty of Nursing UNAIR Surabaya in March-April 2020. The population of respondents was 267 . The sample size in this study was determined using simple random sampling in a population of 267 people; with a confidence level of $95 \%$, and an error rate of $5 \%$, it obtained 160 samples. The dependent variable is awareness in screening, measurement used research questionnaires made by Sabila Okta UNAIR psychology students (Syarafina, 2019) and independent variables are knowledge, social interaction, family support, perceived vulnerability, perceived severity, perceived benefits, perceived obstacles, and trust in the perceived self. The validity test in this study used Pearson product moment ( $r$ ) at SPSS with a significance level of $5 \%$ and resulted in 20 respondents. The reliability test used the Cronbach's alpha formula. If $r$ alpha> $r$ table then the question is reliable, conversely if $r$ alpha $<r$ table then the question is not reliable. Data were analyzed by multiple regression test. This research proposal has passed the ethical test by the Health Research Ethics Committee (KEPK) with the number of ethical certificate No 1957 dated March 28, 2020.

\section{RESULTS}

Respondents' contributions are based on demographic characteristics in 160 students. The data distribution of this study were respondents with the age of 21 years as many as 65 students (40.6\%), the number of female respondents was 138 students $(86.3 \%)$, collected by respondents obtained from semester 8 that were 104 students (65.0\%) and collect respondents to migrate or boarding houses in Surabaya. Respondents having a level of knowledge that is supported in the moderate category totaled 82 respondents $(51.3 \%)$. The number of respondents who participated in the high category was 83 respondents (51.9\%), students who received scholarships in the high category were 83 respondents (51.9\%). A total of 87 respondents $(54.4 \%)$ were accepted by students in the high category. The severity felt in the high category was 79 respondents $(49.4 \%)$. The benefits received in the high category were 98 respondents $(61.3 \%)$, the challenges received by respondents in the moderate category were 86 respondents (53.8\%) and the confidence received by respondents increased in the moderate category by 106 respondents (66. 3\%). Respondents who had low self-awareness in screening psychosocial problems were 67 respondents $(41.9 \%)$ and respondents who had high self-awareness in screening were 93 respondents (58.1\%).

Statistical tests with multiple linear regression obtained the results of social interaction, the assessment received, the benefits received and the self-confidence received related to students' selfawareness in screening for psychosocial problems. Based on the $\mathrm{F}$ test or simultaneous independent results obtained independent variables with the dependent variable with an F count of 24.057 > F table 2.00 and a significance value of $0.00<0.05$. R square was 0.560 , which means the independent variable related to the dependent variable by $56 \%$. The dominant variable in this study is confidence obtained with a standard coefficient of 0.338 .

Based on the table 2, it can be seen that the majority of the respondents' knowledge is in the medium category, namely as many as 82 respondents $(51.3 \%)$. The majority of social interactions in the high category were 83 respondents (51.9\%). The majority of respondents had family support in the high category, namely 83 respondents (51\%). The 
Table 1. Respondents' Characteristics

\begin{tabular}{lccc}
\hline Characteristics & Category & $\mathbf{n}$ & $\mathbf{\%}$ \\
\hline Age & 18 years & 1 & 0.6 \\
& 19 years & 1 & 0.6 \\
& 20 years & 32 & 20.0 \\
& 21 years & 65 & 40.6 \\
Gender & 22 years & 59 & 36.9 \\
& 23 years & 2 & 1,3 \\
Semester & Male & 22 & 13.8 \\
& Girl & 138 & 86.3 \\
Address & 8 & 104 & 65.0 \\
& 6 & 56 & 35.0 \\
\end{tabular}

Table 2. Factors related to Students' Self-Awareness in Conducting Psychosocial Problems Screening

\begin{tabular}{|c|c|c|c|c|c|c|}
\hline Variable & Category & $\mathbf{n}$ & $\%$ & $\begin{array}{c}\text { Standardized } \\
\text { Coefficients (beta) }\end{array}$ & T count & p-value \\
\hline \multirow[t]{3}{*}{ Knowledge } & Low & 13 & 8.1 & -.034 & -.592 & .555 \\
\hline & Medium & 82 & 51.3 & & & \\
\hline & High & 65 & 40.6 & & & \\
\hline \multirow[t]{2}{*}{ Social interactions } & Low & 77 & 48.1 & .235 & 3,945 & .000 \\
\hline & High & 83 & 51.9 & & & \\
\hline \multirow[t]{2}{*}{ Family support } & Low & 77 & 48.1 &,- 021 & -359 & .720 \\
\hline & High & 83 & 51.9 & & & \\
\hline \multirow[t]{3}{*}{ Perceived vulnerability } & Low & 1 & 0.6 & 299 & 4,152 & .000 \\
\hline & Medium & 72 & 45.0 & & & \\
\hline & High & 87 & 54.4 & & & \\
\hline \multirow[t]{3}{*}{ Perceived severity } & Low & 12 & 7.5 & -.124 & $-1,822$ & .070 \\
\hline & Medium & 69 & 43.1 & & & \\
\hline & High & 79 & 49.4 & & & \\
\hline \multirow[t]{3}{*}{ Perceived benefits } & Low & 8 & 5,0 & .242 & 3,344 & .001 \\
\hline & Medium & 54 & 33.8 & & & \\
\hline & High & 98 & 61.3 & & & \\
\hline \multirow[t]{3}{*}{ Perceived obstacles } & Low & 37 & 23.1 & .019 & 322 & .748 \\
\hline & Medium & 86 & 53.8 & & & \\
\hline & High & 37 & 23.1 & & & \\
\hline \multirow[t]{3}{*}{ Perceived self-efficacy } & Low & 7 & 4,4 & .338 & 4,924 & .000 \\
\hline & Medium & 106 & 66.3 & & & \\
\hline & High & 47 & 29.4 & & & \\
\hline \multirow[t]{2}{*}{ Self-awareness } & Low & 67 & 41.9 & & & \\
\hline & High & 93 & 58.1 & & & \\
\hline
\end{tabular}

vulnerability felt by the majority of respondents was in the medium category as many as 72 respondents $(45.0 \%)$. The majority felt the severity in the high category as many as 79 respondents (49.4\%). The benefits felt by the majority in the high category were 98 respondents $(61.3 \%)$. The obstacles felt by the majority were in the medium category as many as 86 respondents (53.8\%). The majority who felt confidence in the medium category was as many as 106 respondents $(66.3 \%)$ and the majority who felt confidence in the high category was as many as 93 respondents (58.1\%). From the table above, it can be seen that the dominant variable in this study is the self-confidence variable with a standardized coefficient value of 0.338 .

\section{DISCUSSION}

\section{Relationship of knowledge with self- awareness}

There is no partial relationship between knowledge and self-awareness of students in screening psychosocial problems, with a significance value of $0.55>0.05$. The knowledge, which consists of six levels in this study, shows the level of respondents in the first level, namely ToFu (Top Of Funnel), and selfawareness indicators consisting of knowledge, understanding, attitudes, and patterns of behavior or action. The aspect of the respondent's self-awareness is still in the knowledge stage, in which is the first stage ToFu). According to Wawan and Dewi (2017). Knowing is defined as memorizing material that has been studied previously, people who already know 
must be able to understand the material or object. Second is understanding (comprehension), the ability to explain an object that was known and interpret the material correctly; the interpretation phase consists of detection, observe an object and identify the characteristics of the objects based on hue, shapes and textures. Analysis is processing and finding the characteristics of the object deeper so that it will produce accurate results, and deduction/classification, namely the conclusion or determination of the type of object (Indarto, 2017). Based on the results of data analysis, it is known that the aspects of signs and symptoms have the lowest value so that this is the background of the respondents' knowledge stage in the first stage (know) because they have not been able to interpret the material correctly. If the first stage of knowledge has been passed it will increase to the next and final stage, namely action. This explains why knowledge is not related to self-awareness because the stage through which self-awareness goes to cause action is still in the first stage so that, in this study, knowledge has no relationship with self-awareness.

\section{The relationship of social interaction with self-awareness}

There is a partial relationship between social interaction with student self-awareness in screening for psychosocial problems with a significance value of $0.000<0.05$. Social interaction is influenced by several things, one of which is motivation, here such as education, work, the desire to fulfill the necessities of life, the desire to add new insights, the desire to create harmony in the community and add experience (Astuti et al., 2018). If someone is aware of the importance of a thing (motivation), it will increase the social interaction of individuals to meet their desires. According to Ira Dwi Puspitasari and Puji Lestari (2015) self-awareness is needed if individuals interact so that they can place themselves in the community. Self-awareness is the background of social interaction, where, with a conscious attitude toward what is inside the individual, both weaknesses and strengths, it will make it easy for someone to understand the potential that is within them, so that they do not experience difficulties to carry out social relations. According to Astuti et al. (2018), social interaction begins with social contact, this is by supported by Herimanto and Winarno who stated that social contact is the beginning of social interaction. One form of social contact is lecture activities in the classroom (Ira Dwi Puspitasari and Puji Lestari, 2015) wherein semester 8 and semester 6 students still often hold lectures in the classroom, so there are social contacts, makinge the majority of student social interactions in the high category.

\section{Relationship of family support with self- awareness}

There is no relationship between family support and self-awareness with a significance value of $0.720>$ 0.05 . The lowest aspect of family support lies in the aspect of valuation support regarding assessment support. According to Anwari (2018), lack of appraisal support due to lack of concern for family members about what is done by respondents, this is supported by the respondents who answered never on the question whether the family cares about the problem at hand. This will have an impact on feelings of disrespect for the actions taken and if this continues it will have an impact on depression. If an individual can understand well the source of stressors and has good coping strategies, the individual has high self-awareness, which means that the individual can understand themselves well, their weaknesses and strengths, so that they can deal with the situation appropriately. Because of this, the third hypothesis is rejected, which means there is no partial relationship between family support and self-awareness.

\section{Relationship of perceived vulnerability with self-awareness}

There is a partial relationship between perceived vulnerability if not screening with student selfawareness in conducting psychosocial screening with a significance value of $0.000<0.05$. Vulnerability perceptions represent an individual's beliefs about risk if they don't have a psychosocial screening. When an individual wants to screen for the first time, they will instinctively collect all the facts and stories, including the risk of screening. Feelings of vulnerability in regard to psychosocial problems and their impact can trigger respondents' awareness of efforts to overcome these problems by screening. If not, they tend to experience the effects of psychosocial problems. Therefore, awareness and subsequent experience have an important role to determine the success of screening (Notoatmodjo, 2010). The more individuals feel their vulnerability regarding their health, the higher the level of individual awareness in conducting the psychosocial screening. The results of this study are consistent with the concept put forward that a person will act if they feel vulnerable to the disease. The positive relationship between perceived vulnerability and self-awareness in conducting psychosocial screening is influenced by patient experience. Experience has an important role that will shape perceptions, such as cognitive, personality, and culture of the individual (Notoatmodjo, 2010) so that the more the person feels vulnerable it will make the individual aware of screening for psychosocial problems. The quality of self-awareness is a clearer state of the individual conscious experience of the present conditions, which effectively realizes memories and anticipates the future (Buglar et al., 2010). This explains how the respondents' vulnerability to the occurrence of 
psychosocial problems and their impact affects and relates to self-awareness; if an individual understands that they are vulnerable to a problem, they will instinctively predict what will happen to them, both now and in the future, so that they arise behavior to anticipate this. The main component of self-awareness is understanding of oneself and secondly the ability to anticipate how a person is valued by others.

\section{Relationship of perceived severity with self- awareness}

With perceived severity if not having screening, there is no positive partial relationship with student selfawareness in conducting psychosocial screening, with a significance value of $0.720>0.05$. Perception of severity is an individual's belief in the severity of a disease. Whereas perceptions of the severity of disease are often based on information or treatment knowledge, it may also come from belief in people who have difficulties with the illness suffered or the impact of the disease on their lives (Buglar et al., 2010). Based on the distribution of questions on this variable, the majority of respondents answered correctly on the question items in my opinion; if they do not do screening, it will have a bad impact on longterm health In addition to this, perception of severity can also be strengthened from information obtained from medical information and mass media, while psychosocial issues themselves have not been given special attention, so that minimal information is conveyed regarding psychosocial and screening issues. Respondents only get this information from lectures in class because it is included in the subject in psychiatric nursing.

\section{Relationship of perceived benefits with self- awareness}

There is a positive partial relationship between the perceived benefits of screening and self-awareness. evidenced by the significance value of $0.001<0.05$. This means that someone who has self-awareness should be fully aware of their perceptions, feelings, dreams, or the world outside of themselves. Humans can realize themselves, a unique and real ability that enables humans to be able to think and decide (Widiatmoko \& Ardini, 2018). This is the background of how the benefits relate to self-awareness,. With someone considering the benefits to be gained after doing something, the individual will decide what they will do and with self-awareness owned by the individual they will determine the benefits that are good for them, So H6 is that the benefits felt after psychosocial screening are partially related to selfawareness. Perceived benefits have an important role in determining behavior for secondary prevention (Buglar et al., 2010). This shows that the perception of the benefits of disease prevention has a positive relationship with student self-awareness in conducting psychosocial screening. The more the patient knows the benefits of these health behaviors, the more aware the respondent is in screening.

\section{Relationship of perceived obstacles with self-awareness}

There is no partial relationship between perceived obstacles and self-awareness of nursing students in conducting the psychosocial screening, as evidenced by the significance value of $0.748>0.05$. Stages of individual self-awareness are determined by the extent to which the individual is trying to enhance their self-awareness. Based on the frequency distribution, the obstacle most felt by individuals is the lack of information, which is one of the efforts to increase self-awareness by conducting communication based on information so that, because of the limited source of information, about screening it is hampering the increase of individual selfawareness. According to Yunti (2019), perceived barrier gets a low proportion of perception because it is the only factor that represents an individual's beliefs about obstacles to doing something. The smaller the obstacles, the higher the patient's compliance. Perceived barriers have an important role in determining behavior change in individuals (Buglar et al., 2010). This proves that respondents who are new to psychosocial screening are likely to face several obstacles that affect their awareness. Students as respondents have obstacles in conducting psychosocial screening; these obstacles can be in the form of internal or external obstacles. Internal barriers include feelings.

\section{Relationship of self-confidence that is felt with self-awareness}

Self-confidence has a significant relationship and has a positive influence on self-awareness in conducting psychosocial screening with a significance value of $0.000<0.05$. Self-confidence is a belief that is owned by individuals who can screen correctly. The belief in new behaviors derived from perceived benefits will increase respondents' self-awareness. Someone's belief in healing a disease will motivate them to take action. This study is in line with research conducted (Indah, 2016; Prasetyowati, 2018) showing that there is a positive effect of confidence in preventive care in type 2 DM patients. Patients with high self-confidence will improve self-care DM 2, where someone who has good self-confidence will be more obedient to preventive behavior to facilitate prevention. According to Chaplin (2002), self-awareness is awareness of one's mental processes or existence as unique individuals. When someone understands and is aware of their emotions, it is easier for them to acknowledge and control emotions. They are also more confident because they do not let their emotions get out of their control. Confidence is a belief in yourself the ability to do something. If someone believes a new behavior is beneficial, but does not 
think they can do it (perceived barrier), chances are that will not be tried (Buglar et al., 2010).

\section{Simultaneous relationship between independent and dependent variables}

There is a simultaneous relationship between variables of knowledge, social interaction, family support, perceived vulnerability, perceived severity, perceived benefits, perceived obstacles, and selfconfidence with self-awareness on students in screening psychosocial problems, with a calculated $\mathrm{F}$ value of $24.057>\mathrm{F}$ table 2.00 and a significance value of $0.000<0.05$ so that it can be interpreted that there is a simultaneous influence of knowledge variables, social interaction, family support, perceived vulnerability, perceived severity, perceived benefits, perceived obstacles, and confidence in self-awareness variables. $\mathrm{R}$ square value of 0.560 means that the independent variable simultaneously influences the dependent variable by $56 \%$, and other variables affect self-awareness by $44 \%$, but in this study were not examined. Based on the results of the regression coefficient (B) it is known that self-efficacy has the greatest value of 0.338 compared to other variables. So self-confidence has the most influence on student self-awareness in conducting psychosocial screening. Where if someone has a high self-efficacy will increase preventive behavior to facilitate prevention (Holm-Hadulla \& Koutsoukou-Argyraki, 2015) .Psychosocial screening is an effort to prevent the worse effects due to existing psychosocial problems, so psychosocial screening is a preventive program for the prevention of disease. Self-efficacy is an individual's belief in acting so that if the individual already has high confidence, it will be easy to carry out a health behavior. Research (Phillips \& Silvia, 2005) states that self-efficacy is the most powerful factor for determining compliance. Ormel et al. (2020) say that humans are creatures that can be aware of and are, therefore, responsible for their existence. Individuals with strong instincts of selfawareness can know when they feel less excited, easily upset, sad, or excited and realize how these various feelings can change their behavior, which causes others to feel uncomfortable. A person's ability to recognize their feelings and the way he responds, makes them able to control behavior that has the potential to harm them. Knowledge, social interaction, family support, perceived vulnerability, perceived severity, perceived obstacles, perceived benefits, and self-confidence together influence selfawareness, wherewith the existence of broad insight and external support.

\section{CONCLUSION}

There is a relationship in social interaction variables, perceived vulnerability, perceived benefits, and perceived confidence while the variables of knowledge, family support, perceived severity, and perceived obstacles do not have a positive relationship with self-awareness of students in screening for psychosocial problems. This dilator is due to many factors, both from the internal and external of the individual. The recommendation in this study is that there is a need for health education on mental emotional health that focuses on how to prevent psychosocial problems because these problems are most often experienced by students, and it is necessary to provide information about psychosocial problems as well as psychosocial screening that is easily accessible to students.

\section{REFERENCES}

Andriyani, A., \& Widigdo, J. (2017). Model Layanan Screening Dalam Konseling Kesehatan Mental Berbasis Android (E-Couns) Untuk Mendukung Gerakan Revolusi Mental. Seminar Bimbingan Dan Konseling, 1(1), 96-103.

Anwari, misbakhul. (2018). Hubungan Dukungan Keluarga dengan Kualitas Hidup Lansia yang Mengalami Hipertensi di Wilayah Kerja Puskesmas Mandalle Kabupaten Pangkep. September, 160164.

Ashley, G., \& Reiter-Palmon, R. (2012). SelfAwareness and the Evolution of Leaders: The Need for a Better Measure of Self-Awareness. Journal of Behavioral Applied Management, 14(1), 2-17.

Astuti, P. D., Hadiwinarto, H., \& Sholihah, A. (2018). Studi Deskriptif Interaksi Sosial Mahasiswa S1 Jurusan Ilmu Pendidikan Berdasarkan Keterlibatan Organisasi Kemahasiswaan Di Fakultas Keguruan Dan Ilmu Pendidikan Universitas Bengkulu. Consilia: Jurnal Ilmiah Bimbingan Dan Konseling, 1(2), 20-28. https://doi.org/10.33369/consilia.1.2.20-28

Buglar, M. E., White, K. M., \& Robinson, N. G. (2010). The role of self-efficacy in dental patients' brushing and flossing: Testing an extended Health Belief Model. Patient Education and Counseling, 78(2), 269-272. https://doi.org/10.1016/j.pec.2009.06.014

FARISA, I. I. (2016). Hubungan Pola Asah Pengasuh dengan Perkembangan Motorik Anak Usia Prasekolah (3-5 Tahun) di TPA Taam Ananda Surabaya. Universitas Airlangga.

Holm-Hadulla, R. M., \& Koutsoukou-Argyraki, A. (2015). Mental health of students in a globalized world: Prevalence of complaints and disorders, methods and effectivity of counseling, structure of mental health services for students. Mental Health and Prevention, 3(1-2), 1-4. https://doi.org/10.1016/j.mhp.2015.04.003

Indarto. (2017). Penginderaan Jauh: Metode Analisis \& Interpretasi Citra.

Ira Dwi Puspitasari dan Puji Lestari, M. H. (2015). The Factors Behind The Social Interaction Between The Public Samin And The Non-Samin Community ( Community Studies Padukuhan Karangpace Klopoduwur Village, Banjarejo District, Blora Regency, Central Java).

Manurung, lisma nurlina. (2018). Asuhan 


\section{V.S. PUTRI ET AL.}

Keperawatan Keluarga. Fakultas Ilmu Kesehatan Ump, 2010, 8-42.

Notoatmodjo. (2010). Pendidikan dan Perilaku Kesehatan. Rineka Cipta.

Ormel, J., Cuijpers, P., Jorm, A., \& Schoevers, R. A. (2020). What is needed to eradicate the depression epidemic, and why. Mental Health and Prevention, 17(December), 200177. https://doi.org/10.1016/j.mhp.2019.200177

Phillips, A. G., \& Silvia, P. J. (2005). Self-awareness and the emotional consequences of self-discrepancies. Personality and Social Psychology Bulletin, 31(5), 703-713.

https://doi.org/10.1177/0146167204271559

Prince, H., \& Alexander, L. (2017). Self-awareness: There is no cure and no improving of the world that does not begin with the individual himself .
Insights, 7, 1-11.

RISKESDAS. (2018). HASIL UTAMA RISKESDAS 2018. Jakarta: Salemba Medika: Kementerian Kesehatan RI Badan Penelitian dan Pengembangan Kesehatan.

Syarafina, S. O. (2019). Pengaruh Optimisme dan Kesadaran Diri Terhadap Adversity Quotient Pada Mahasiswa Universitas Negeri Malang yang Menempuh Skripsi Sambil Bekerja.

Wawan, A., \& Dewi, M. (2017). Teori \& Pengukuran Pengetahuan, Sikap, Dan Perilaku Manusia (Kedua). Yogyakarta: Nuha Medika.

Widiatmoko, M., \& Ardini, F. M. (2018). Pendekatan konseling analisis transaksional untuk mengembangkan kesadaran diri remaja. Jurnal Kajian Pendidikan Dan Pengajaran, 4(2), 99-108. https://doi.org/10.30653/003.201842.50 